\title{
ARE ALVEOLAR BONE CHANGES A DETERMINANT FACTOR FOR "CARA INCHADA" IN CATTLE ?'1
}

\author{
Jürgen Döbereiner ${ }^{2}$ and Klaus Dämmrich ${ }^{3}$
}

\begin{abstract}
Döbereiner J. \& Dämmrich K. 1997. Are alveolar bone changes a determinant factor for "cara inchada" in cattle? Pesquisa Veterinária Brasileira 17(2):45-48. Projeto Saúde Animal Embrapa/UFRRJ, Km 47, Seropédica, Rio de Janeiro 23851-970, Brazil.

In order to study possible alterations of the skeleton which might play a role in the pathogenesis of the periodontitis of "cara inchada" in young cattle, ribs from 20 affected calves, 2 to 10 months old, were examined. Electrolytically decalcified longitudinal sections of the costochondral junction and cross sections through the corpus costae, stained with Haematoxylin-Eosin, were studied. In five calves, longitudinal sections of the proximal humerus were examined as well. The status of mineralization was checked by microradiograms. Systemic alteration of the skeleton due to disturbances of mineral metabolism could not be shown in any of the animals. In seven 2 to 4 months old calves, no bone changes were found. The reduced osteogenesis in six 3 to 5 months old calves and the reduced osteogenesis and diminished chondral growth in seven 5 to 10 months old calves are therefore a consequence of the disease. The results show that the development of the alveolar bone was not defective, so this cannot be a determinant factor for the development of the periodontitis of "cara inchada" in cattle.
\end{abstract}

INDEX TERMS: “Cara inchada”, periodontitis, cattle, pathogenesis, skeleton, bone histopathology.

SINOPSE.- Alterações do osso alveolar são um fator determinante da "cara inchada" dos bovinos? Para verificar possíveis alterações do esqueleto, que poderiam ter papel importante na patogênese da periodontite da "cara inchada"em bovinos jovens, costelas de 20 bezerros com 2 a 10 meses de idade e afetados pela doença foram estudadas. Examinaram-se cortes longitudinais eletroliticamante descalcificados das junções cartilaginosas e cortes transversais do corpus costae, corados pela hematoxilina-eosina. Em cinco bezerros examinaram-se também cortes longitudinais do úmero proximal. $O$ estado de mineralização óssea foi avaliado através de microrradiogramas. Em nenhum dos animais alterações do esqueleto por distúrbios do metabolismo mi-

\footnotetext{
1 Accepted for publication on February 14, 1997.
}

The research project received the financial support of $C N P q / D A A D$, agreement Brazil/Germany, and was carried out in collaboration with the Institut of Veterinary Pathology of the Free University Berlin, Germany.

2 Projeto Saúde Animal Embrapa/UFRRJ, Km 47, Seropédica, RJ 23851-970, Brazil; Research Fellow of CNPq (305294/88-1).

3 Formerly at the Institut für Veterinär-Pathologie, Freie Universität Berlin, Strasse 518, Nr.15, D-14163 Berlin, Germany. neral podiam ser demonstradas. Nos bezerros com 2 a 4 meses de idade nenhuma alteração patológica do esqueleto foi encontrada. Por isso, a osteogênese reduzida observada nos bezerros com 3 a 5 meses de idade, bem como a osteogênese e o crescimento cartilaginoso reduzidos nos bezerros de 5 a 10 meses de idade, devem ser interpretados como consequências da doença. Os resultados desse estudo demonstram que não existe um desenvolvimento deficiente do osso alveolar como fator predisponente para o desenvolvimento da periodontite da "cara inchada" nos bovinos.

TERMOS DE INDEXAÇÃO: “Cara inchada”, periodontite, bovinos, patogênese, esqueleto, histopatologia óssea.

\section{INTRODUCTION}

Weakening of the periodontal tissue, especially a faulty development of the alveolar bone, is often held as a predisposing factor of the multifactorial pathological picture of "cara inchada" of cattle (CI), a progressive purulent periodontitis in calves in Brazil causing emaciation and often death. The developing periodontal pouches would favor the entrance of food particles and bacteriae. Mainly affected is the region of the maxillar teeth $\mathrm{Pd}_{3}-\mathrm{Pd}_{4}$, uni- or bilaterally. 
The periodontal lesions may result in loss of teeth accompanied by a considerable lateral enlargement of the upper jaw. As a possible cause of the faulty development of the alveolar bone, disturbances of the mineral metabolism in form of a secondary hyperparathyroidism have been discussed; this would lead to resorption of the alveolar bone by fibrous osteodystrophy (Nunes et al. 1979, Brito 1983, Souza 1987, Nunes 1996). On the other hand, a protein deficiency could cause osteopenia (osteoporosis) with a hypoplastic development of the alveolar bone.

Twenty calves with $\mathrm{CI}$ were examined in order to study the simultaneous occurrence of $\mathrm{Cl}$ and a possible systemic bone disease as causes of faulty development of the alveolar bone.

\section{MATERIALS AND METHODS}

During field work investigating the disease, ribs of 20 calves with $\mathrm{CI}$, 2 to 10 months of age, and in some cases also the humerus were collected and fixed in $10 \%$ neutral formalin for histological examination. The calves of pure or mixed Zebu breed were necropsied on farms in the states of Mato Gosso, Mato Grosso do Sul and Goiás, Brazil, between 1982 and 1984 when the incidence of $\mathrm{Cl}$ in CentralWestern Brazil was still quite high. Longitudinal sections of the costochondral junction of the ribs and cross sections of the corpus costae were studied from all animals. In five cases longitudinal sections of the proximal humerus were also examined. The material was electrolytically decalcified and stained with Haematoxylin-Eosin. Simultaneously the degree of mineralization of the bone tissue was evaluated by microradiograms after embedding the cross sections of the ribs in Methylmetacrylate.

\section{RESULTS}

Calves without signs of systemic bone diseases (Table 1)

The ribs show a thick growth plate with long cellular dense columns of chondrocytes and distinct differentiation in the proliferating zone, hypertrophic zone and zone of vacuolated chondrocytes. The cartilage cell columns are resorbed individually, so that a dense network of calcified longitudinal septa remains. In some distance from the growth plate woven bone tissue is deposited in small layers on the septa. The metaphyseal primary spongiosa changes to secondary spongiosa due to the reduction in number of the longitudinal spicules and an arising transverse network. The thicker trabeculae of the secondary spongiosa are frequently tied together by apposition of bone tissue. The metaphyseal compacta near the physis is closed to a thin mantle by endosteal apposition of bone tissue on the primary isolated spongy trabeculae. Subperiosteally occur small resorption lacunae, caused by osteoclasts of remodeling. Active remodeling happens in the diaphyseal costal compacta. The lateral periosteal part shows a distinct formation of radial und tangential lamellae, which include vascular channels. The vascular channels are narrowed by apposition of lamellated bone tissue. Consequently the Haversian channels in the inner part of the lateral compacta have a narrow lumen and are surrounded by primary Haversian systems with thick lamellae. The pleural side of the compacta of the ribs present subperiosteally flat resorption lacunae of remodeling. Endosteally a layer of bone tissue is being apposed on the inner side of the pleural compacta and on the spongy trabeculae, which set on the compacta.

The bone tissue is regularly mineralized. Small osteoid borders are seen at the newly formed subperiosteal lamellae and in some Haversian channels.

\section{Calves with signs of reduced osteogenesis (Table 2)}

The growth plate of the ribs contains cellular dense columns of proliferating chondrocytes. The columns are resorbed individually as regulary so that a regular network of longitudinal septa of calcified matrix develops. On the remaining septa woven bone tissue is apposed only in small borders, but only on few of the longitudinal septa. In consequence metaphyseally a disconnected and wide-mashed secondary spongiosa with thin trabeculae develops. In the metaphyseal compacta the trabecular structure can be recognized up to the transition in the diaphyseal compacta, due to the reduced endosteal apposition of bone tissue. Subperiosteally occur few lacunae of resorption with small osteoclasts, mostly with only one nucleus. The lateral part of the diaphyseal compacta is covered periosteally by a decreased number of newly formed lamellae. Because of the shortened radial lamellae the tangential lamellae are laid down at the surface of the compacta enclosing small cleftshaped vascular channels. In the deeper layers of the lateral compacta the Haversian channels appear to be wider. They

Table 1. Calves without signs of a systemic disease of the skeleton

\begin{tabular}{|c|c|c|c|c|c|c|c|c|}
\hline \multirow{2}{*}{$\begin{array}{c}\text { Bovine } \\
\text { no. }\end{array}$} & \multirow{2}{*}{$\begin{array}{c}\text { Age } \\
\text { (months) }\end{array}$} & \multirow[t]{2}{*}{ Sex } & \multirow{2}{*}{$\begin{array}{l}\text { Farm of } \\
\text { origin }\end{array}$} & \multirow[t]{2}{*}{ County } & \multirow[t]{2}{*}{ State } & \multirow{2}{*}{$\begin{array}{c}\text { Enlargement } \\
\text { of maxillar bone }\end{array}$} & \multicolumn{2}{|c|}{ Maxillar periodontal lesions } \\
\hline & & & & & & & Teeth involved & Severity \\
\hline 4570 & 2 & $\mathrm{~m}$ & S.J. & Rondonópolis & MT & Without - & $\mathrm{Pd}_{3}-\mathrm{Pd}_{4}$ unilateral & $(+)$ \\
\hline 4571 & 2 & $\mathrm{f}$ & S.A.J. & Pedra Preta & MT & Bilateral +++ & $\mathrm{Pd}_{2}-\mathrm{Pd}_{4}^{4}$ bilateral & $+++^{a}$ \\
\hline 4572 & 2 & f & S.A.J. & Pedra Preta & MT & Bilateral ++ & $\mathrm{Pd}_{2}^{2}-\mathrm{Pd}_{4}^{4}$ bilateral & ++ \\
\hline 4589 & 3 & $\mathrm{~m}$ & Pc. & Rondonópolis & MT & Bilateral + & $\mathrm{Pd}_{3}^{2}-\mathrm{Pd}_{4}^{4}$ bilateral & + \\
\hline 4593 & 3 & $\mathrm{~m}$ & Pr. & Camapuã & MS & Without - & $\mathrm{Pd}_{3}-\mathrm{Pd}_{4}$ unilateral & + \\
\hline 4594 & 3 & $\mathrm{~m}$ & Pr. & Camapuã & MS & Without - & $\mathrm{Pd}_{3}-\mathrm{Pd}_{4}$ bilateral & + \\
\hline 4590 & 4 & $\mathrm{f}$ & Pc. & Rondonópolis & MT & Bilateral + & $\mathrm{Pd}_{2}-\mathrm{Pd}_{4}$ bilateral & + \\
\hline
\end{tabular}

a +++ Extreme, ++ great, + moderate, - without enlargement.

b ++ Rather advanced, + advanced, (+) distinct macroscopic lesions. 
Table 2. Calves with reduced osteogenesis

\begin{tabular}{|c|c|c|c|c|c|c|c|c|}
\hline \multirow{2}{*}{$\begin{array}{c}\text { Bovine } \\
\text { no. }\end{array}$} & \multirow{2}{*}{$\begin{array}{c}\text { Age } \\
\text { (months) }\end{array}$} & \multirow[t]{2}{*}{ Sex } & \multirow{2}{*}{$\begin{array}{l}\text { Farm of } \\
\text { origin }\end{array}$} & \multirow[t]{2}{*}{ County } & \multirow[t]{2}{*}{ State } & \multirow{2}{*}{$\begin{array}{c}\text { Enlargement } \\
\text { of maxillar bone }\end{array}$} & \multicolumn{2}{|c|}{ Maxillar periodontal lesions } \\
\hline & & & & & & & Teeth involved & Severity \\
\hline 4588 & 3 & $\mathrm{~m}$ & Pc. & Rondonópolis & MT & Bilateral $+^{\mathrm{a}}$ & $\mathrm{Pd}_{3}-\mathrm{Pd}_{4}$ bilateral & $+^{b}$ \\
\hline 4561 & 4 & $\mathrm{~m}$ & $\mathrm{Br}$. & Bandeirantes & MS & Bilateral ++ & $\mathrm{Pd}_{3}-\mathrm{Pd}_{4}$ bilateral & + \\
\hline 4566 & 4 & $\mathrm{~m}$ & $\mathrm{Br}$. & Bandeirantes & MS & Without - & $\mathrm{Pd}_{3}-\mathrm{Pd}_{4}$ unilateral & $(+)$ \\
\hline 4567 & 4 & $\mathrm{f}$ & $\mathrm{Br}$. & Bandeirantes & MS & Bilateral $(+)$ & $\mathrm{Pd}_{3}^{3}-\mathrm{Pd}_{4}^{4}$ bilateral & + \\
\hline 4565 & 5 & $\mathrm{f}$ & $\mathrm{Br}$. & Bandeirantes & MS & Unilateral (+) & $\mathrm{Pd}_{3}^{3}-\mathrm{Pd}_{4}^{4}$ unilateral & + \\
\hline 4568 & 5 & $\mathrm{f}$ & $\mathrm{Br}$. & Bandeirantes & MS & Bilateral +++ & $\mathrm{Pd}_{3}-\mathrm{Pd}_{4}^{4}$ bilateral & ++ \\
\hline
\end{tabular}

a +++ Extreme, ++ great, + moderate, - without enlargement.

b ++ Rather advanced, + advanced, $(+)$ distinct macroscopic lesions.

are surrounded by thin primary lamellae. In contrast, the pleural part of the compacta is more solid and contains narrow Haversian channels. Endosteally almost no apposition of bone tissue can be observed. The subperiosteal remodeling is with few flat resorption lacunae less evident.

The mineralization of the bone tissue is regular. Only few of the Haversian channels are surrounded by small osteoid borders.

Calves with reduced osteogenesis and decreased chondral growth (Table 3)

The epiphyseal plates of the ribs (and in three calves also the epiphyseal plate of the proximal humerus) show a decreased proliferation of chondrocytes, which are arranged in short columns. In the short columns with only few cells the differentiation in hypertrophic and vacuolated chondrocytes is missed. The columns of chondrocytes are not resorbed individually. The flat resorption lacunae cover groups of columns so that only few short longitudinal septa of calcified cartilaginous matrix remain. On these trabeculae of calcified cartilaginous matrix and directly on the metaphyseal plate bone tissue is laid down. Correspondingly only few metaphyseal trabeculae develop. The metaphysis contains only a wide-mashed network of thin secondary trabeculae which often fasten directly to the epiphyseal plate. The thin metaphyseal compacta is composed of single trabeculae, which are seldom connected by endosteal apposition of bone tissue. Frequently isolated single trabeculae occur on the inner side of the metaphyseal compacta. These trabeculae are embedded in endosteal fibrous tissue of lower density of fibres. Only few small osteoclasts are seen in flat resorption lacunae. The diaphyseal compacta is represented by a thin closed cortex. The lateral compacta includes wider Haversian channels, surrounded by thin lamellae of primary osteons. Periosteally there is no development of radial and tangential lamellae. The lateral compacta is separated from the periosteum by a thin lamella of bone tissue. In two calves ( 9 and 10 months old) the thicker apposed lamella includes some cleft-shaped narrow vascular channels. The apposed lamella is separated from the cortical bone by a distinct basophil resting line. The likewise thin pleural compacta shows subperiosteally a flat zone of resorption, but no resorbing cells exist. Mainly the pleural compacta is composed of interstitial lamellae, which result from the endosteal apposition of bone tissue. Only few primary osteons with wide vascular channels are included.

The microradiographic examination shows regular mineralization of the bone tissue. Corresponding to the reduced osteogenesis only few Haversian channels are surrounded by small osteoid borders.

\section{DISCUSSION AND CONCLUSIONS}

The histological and microradiographic examinations of the skeleton of the 20 by $\mathrm{CI}$ affected calves were done on their ribs, because in generalized diseases of the skeleton the ribs show the first and most distinct alterations.

In none of the calves a disease of the skeleton due to disturbances of the mineral metabolism could be

Table 3. Calves with reduced osteogenesis and diminished chondral growth

\begin{tabular}{|c|c|c|c|c|c|c|c|c|}
\hline \multirow{2}{*}{$\begin{array}{l}\text { Bovine } \\
\text { no. }\end{array}$} & \multirow{2}{*}{$\begin{array}{c}\text { Age } \\
\text { (months) }\end{array}$} & \multirow[t]{2}{*}{ Sex } & \multirow{2}{*}{$\begin{array}{c}\text { Farm of } \\
\text { origin }\end{array}$} & \multirow[t]{2}{*}{ County } & \multirow[t]{2}{*}{ State } & \multirow{2}{*}{$\begin{array}{c}\text { Enlargement } \\
\text { of maxillar bone }\end{array}$} & \multicolumn{2}{|c|}{ Maxillar periodontal lesions } \\
\hline & & & & & & & Teeth involved & Severity \\
\hline 4560 & 5 & $\mathrm{~m}$ & $\mathrm{Br}$. & Bandeirantes & MS & Unilateral $+++^{\mathrm{a}}$ & $\mathrm{Pd}_{3}-\mathrm{Pd}_{4}$ unilateral & $++^{b}$ \\
\hline 4563 & 5 & $\mathrm{~m}$ & $\mathrm{Br}$. & Bandeirantes & MS & Bilateral $(+)$ & $\mathrm{Pd}_{3}^{3}-\mathrm{Pd}_{4}$ bilateral & + \\
\hline 4562 & 6 & $\mathrm{~m}$ & $\mathrm{Br}$. & Bandeirantes & MS & Bilateral ++ & $\mathrm{Pd}_{3}-\mathrm{Pd}_{4}$ bilateral & + \\
\hline 4595 & 6 & $\mathrm{~m}$ & $\mathrm{Br}$. & Camapuã & MS & Bilateral ++ & $\mathrm{Pd}_{2}-\mathrm{Pd}_{4}$ bilateral & +++ \\
\hline 4557 & 7 & $\mathrm{~m}$ & M.A. & Caiapônia & GO & Bilateral ++ & $\mathrm{Pd}_{2}-\mathrm{Pd}_{4}$ bilateral & +++ \\
\hline 4564 & 9 & $\mathrm{~m}$ & $\mathrm{Br}$. & Bandeirantes & MS & Bilateral +++ & $\mathrm{Pd}_{3}-\mathrm{Pd}_{4}$ bilateral & +++ \\
\hline 4556 & 10 & $\mathrm{~m}$ & C.B. & Cassilândia & MS & Bilateral (+) & $\mathrm{Pd}_{3}-\mathrm{Pd}_{4}$ bilateral & + \\
\hline
\end{tabular}

a +++ Extreme, ++ great, $(+)$ slight enlargement.

b +++ Very much advanced, ++ rather advanced, + advanced macroscopic lesions. 
demonstrated. This applies to Osteodystrophia fibrosa as symptom of a secondary hyperparathyroidism in dietetic Cadeficiency and/or P-excess. Disturbances of mineralization of the newly formed bone tissue, in the sense of Rickets or Osteomalacia, due to a dietetic P-deficiency, could also not be established. Correspondingly, the parathyroid glands collected from three calves, did not show signs of increased secretory activity and the parenchyma consisted exclusively of inactive dark chief cells. Therefore the assumption, that disturbances of mineral metabolism favor the formation of periodontal pouches around $\mathrm{Pd}_{3}-\mathrm{Pd}_{4}$ because of faulty development of the alveolar bone, was not supported.

In earlier investigations it was suspected that with $\mathrm{CI}$ affected calves have a reduced osteogenesis or osteopenia/ osteoporosis (Brito 1983, Soni 1984, Souza 1987, Dämmrich pers. commun. apud Döbereiner 1990). Here again it appeared possible that a reduced osteogenesis could lead to a hypoplastic development of the alveolar bone and to the formation of periodontal pouches.

This study on the 20 calves with $\mathrm{CI}$ now proved, that a reduced osteogenesis was not always present. In seven calves no signs of a reduced osteogenesis were found. Six calves showed signs of a reduced osteogenesis. In the other seven calves, the osteogenesis was more distinctly reduced and was accompanied by diminished chondral growth. There was a correlation between the age of the animals and the duration of the disease. Six of the seven calves with a normal formation of the skeleton were 2 to 3 months and only one was 4 months old (Table 1). On the other hand, five of the six calves with a reduced osteogenesis were 4 to 5 months and only one was 3 months old (Table 2), and the seven calves with a reduced osteogenesis and a diminished chondral growth were 5, 6, 7, 9 and 10 months of age (Table 3).

From these results it can be concluded, that the reduced osteogenesis does not exist at the initial stages of $\mathrm{CI}$, as it occurred in our seven 2 to 4 months old calves. Accordingly, it can be supposed that at the initial stage of $\mathrm{CI}$ there is no hypoplastic development of the alveolar bone, which could favour the infection and inflammation of the periodontal tissue.
The reduced osteogenesis in the six 3 to 5 months old calves, as well as the reduced osteogenesis and diminished chondral development in the seven 5 to 10 months old calves, should be interpreted as consequences of $\mathrm{CI}$. Reduced food intake and the impaired general state of health due to the infection and inflammation of the periodontium and to the often occurring diarrhea appear to induce energy deficiency with catabolic metabolism. In longer diseased calves the catabolic metabolism is followed by hypoplastic osteogenesis (osteoporosis). With longer duration of the disease, the hypoplastic osteogenesis continues and is accompanied by decreased chondral growth (stunted growth).

From these findings it can be concluded that in the pathogenesis of $\mathrm{CI}$, there is no faulty development of the alveolar bone. So it could not play a role as a determinant factor in the onset of the inflammatory process at the marginal gingiva, which finally results in the pathological picture of the disease in young cattle (Döbereiner et al. 1974, Döbereiner 1990).

\section{REFERENCES}

Brito L.A.B. 1983. Aspectos morfológicos da "doença periodontal" em bovinos. M.Sc. Thesis, Esc. Vet. UFMG, Belo Horizonte. 52 p.

Döbereiner J. 1990. Zur Ätiologie der “Cara inchada”, einer parodontalen Erkrankung der Jungrinder in Brasilien [Towards the etiology of "Cara inchada", a periodontal disease of young cattle in Brazil]. Dtsch. Tierärztl. Wschr. 97(11):482-490.

Döbereiner J., Inada T. \& Tokarnia C.H. 1974. "Cara inchada”, doença peridentária em bovinos. Pesq. Agropec. Bras., Sér. Vet. 9:63-85.

Nunes V.A. 1996. Doença periodontal (“cara inchada”) dos bovinos. Cad. Téc. Esc. Vet. UFMG, Belo Horizonte, no. 15, p. 5-26.

Nunes V.A., Viana J.A.C., Nunes I.J., Carvalho A.V. Santos B.M., Ribeiro H.M. \& Teixeira T. 1979. Doença periodontal (“cara inchada”) em bovinos do Estado de Goiás. Aspectos morfológicos. Arqs Esc. Vet. UFMG, Belo Horizonte, 31(3):283-296.

Soni C.A. 1984. Influência do cálcio, do fósforo e do cobre na "doença periodontal”do bovino. M.Sc. Thesis, Esc. Vet. UFMG, Belo Horizonte. 51 p.

Souza V.T.F. 1987. Aspectos morfológicsos do fêmur, do úmero e de vértebras lombares em bovinos jovens afetados de doença periodontal. M. Sc. Thesis, Esc. Vet. UFMG, Belo Horizonte. 46 p. 